\title{
Porteño Spanish: Background and Previous Research
}

This chapter offers background information regarding the linguistic varieties in question, Argentinean and Uruguayan Spanish. A brief sketch of the sociolinguistic contexts is provided, as this is relevant to the discussion on contact-induced change in 7.8. In addition, I provide a summary of linguistic features idiosyncratic to these two varieties, as opposed to the remaining Latin American varieties.

\section{1}

\section{Sociolinguistic Context}

Porteño Spanish is the urban vernacular spoken in Buenos Aires, Argentina. Buenos Aires Spanish is sometimes also referred to as River Plate Spanish, Rioplatense Spanish, and Bonaerense (but should not be confused with Lunfardo or Cocoliche; see section 3.3.2.5). When referring to the Uruguayan variety, this will be specified.

There is a tradition in Hispanic linguistics to encompass linguistic varieties from both the Uruguayan and the Argentinean parts of the Río de la Plata under the same umbrella, titling the area the River Plate zone (Lipski 1994). This tradition may be due to a lack of studies on the Uruguayan variety. Lipski's claim (ibid.: 337) that "Uruguayan speech is simply an extension of the Porteño speech of Buenos Aires" stands as a representation of similar claims and is itself a huge simplification. Uruguayan Spanish differs from Argentinean in prosody, morphology, and morphosyntax (Elizaincín 1981).

Porteño Spanish has an estimated 16 million speakers. ${ }^{1}$ As we shall see, Porteño Spanish is a relatively well-studied variety of Spanish, and it is known to have lexical, phonological, prosodic, morphological, and syntactical idiosyncrasies. Some of these idiosyncrasies have roots in sociolinguistic factors unique to the area, while others do not. In the following section, I provide an overview of the sociohistorical context in which Buenos Aires developed

1 No official number exists. The proposed number comprises the provinces of Buenos Aires and Entre Ríos (see indec.gov.ar). 
before I present a more detailed description of the linguistic features of Porteño Spanish itself.

\subsection{Sociohistorical Context}

Argentina was colonized by the Spaniards in the early 16th century, and Buenos Aires was first established in 1536 by Pedro de Mendoza. The estuary in which the rivers Paraná and Uruguay converge was named Río de la Plata, Silver River, since it was assumed that the river hid great mineral wealth. The native indigenous population was hostile to the Spanish advances and managed to force the population of Buenos Aires to evacuate to Paraguay a few years after its first establishment. These attempts delayed the permanent settlement of Buenos Aires, and it was reestablished in 1580 . Despite the initial attempts at resistance, the native indigenous population - called the querandíes-were few in number and were eventually forced to evacuate the Pampas, leaving Buenos Aires an area with minimal indigenous presence and linguistic influence, except for a few loans (Lipski 1994: 164; see also 7.8). In 1617, Buenos Aires became the capital of the colonial province of Río de la Plata. Its importance grew steadily as the route over the Atlantic from Buenos Aires to Europe was a short and economical way to transport goods. Eventually, Buenos Aires grew to full importance in 1776 , when the Viceroyalty of Río de la Plata, comprising present-day Argentina, Uruguay, Paraguay, and Bolivia, was established. Buenos Aires soon became a social and cultural focal point of South America, owing to a growth that would only increase throughout the centuries to come.

Argentina received African slaves throughout the colonial period, most of whom resided in Buenos Aires. Even though their impact on Argentine society was important at one point (through, e.g., music, and also reflected in loanwords, such as the typical Porteño Spanish word for 'maid', muсama), they declined immensely in number starting in the early 19th century. Today, they are a largely invisible group, even though more than $4 \%$ of the Argentine population has African ancestors. There is no consensus concerning how to interpret the African population's decline, but explanations such as warfare, emigration to countries with larger African communities (such as Uruguay and Brazil), epidemics, and even state-induced genocide have been proposed (Fejerman et al. 2005).

Argentina was declared independent in 1816 . The first constitution, dating to 1819 , allowed for immigration from all countries that were not at war with Argentina, and the eventual constitution even promoted immigration "by all possible means." Immigration was promoted to populate the land and to 
introduce labor, but also to impose European culture on the local population. European and Anglo-Saxon immigration were seen as the carriers of civilization and progress. Note, however, that once the immigrants arrived, the politics to assimilate them into local national culture was strong, as reflected in, e.g., the monolingual (Spanish) education and their rapid shift to Spanish (see also discussion in 7.8). Immigration policies induced massive waves of immigrants to Argentina, and especially to the port capital Buenos Aires. Between 1856 and 1932 , Argentina received 6.5 million immigrants. In 1887 , the majority $(53 \%)$ of Buenos Aires's inhabitants were immigrants. Of them, approximately $32 \%$ were Italian, $9 \%$ Spanish, $5 \%$ French, and the remaining $7 \%$ of different nationalities (Armenian, Russian, Polish, English, etc.) (Conde 2011: 149). Italians made up the overwhelming majority of the immigrants.

Both Italian and Spanish immigrants' assimilation into Argentinean society and culture is assumed to have proceeded with relative ease (Conde 2011; Fontanella de Weinberg 1979; Klee \& Lynch 2009: 185-186). For Spanish immigrants, speaking the same language as the descendants of the colonizers was an obvious facilitator in the assimilation, in addition to the many cultural and religious similarities.

For Italians, the shift to Spanish occurred rapidly. As with the Spanish immigrants, cultural and religious similarities are assumed to have contributed to the Italians' rapid shift to Spanish. These immigrants were in fact seen as vital contributors to the society's development, and their adaptation into Argentinean society was rapid — and so was their shift to the majority language. Three factors are assumed to have contributed to this rapid shift (Klee \& Lynch 2009: 185-191): (1) the lack of uniformity in the immigrants' Italian varieties-the immigrants did not speak standard Italian but different, often mutually unintelligible dialects and so had no lingua franca; (2) the genetic and typological proximity to Spanish - it was not a difficult task for them to learn Spanish; and (3) pressure from the free and obligatory monolingual education system.

Galician speakers also shifted rapidly to Spanish-again, presumably because of the stigma associated with the Galician language, because of the proximity to Spanish, and also because Galicians were subject to mocking and degradation in Buenos Aires society. Others shifted with differing speed: German-speaking Russians, for example, preserved their language to a much greater extent than did Italians. Among Yiddish speakers, one could find a difference between those in agriculture and those from urban centers: the urban dwellers were less likely to preserve their language. French and Occitan speakers shifted rapidly — again, possibly due to cultural, religious, and linguistic proximity-while English speakers largely preserved their language (see Fontanella de Weinberg 1979 for an in-depth analysis). 
Overall, the speed at which assimilation occurred was largely facilitated by the education system, which was imposed on all citizens through Ley 1420 de educación común, from 1884, providing public, monolingual, obligatory, and free education. The law had the explicit aim of assimilating immigrants, and it succeeded, resulting in widespread literacy. It was common for illiterate parents to see their children go on to pursue university careers. Argentina thus represented the possibility for rapid upward social mobility. There was a motivation to speak Spanish in order to ascend socially, and many parents wanted their children to learn Spanish precisely because they knew that knowing the majority language would increase their children's possibilities for successful lives and careers.

\subsubsection{Río de la Plata Today}

Buenos Aires still is the economic, cultural, and political center of Argentina and of the Río de la Plata region. In 2010, Argentina had approximately 40 million inhabitants, of which Buenos Aires (the greater metropolitan area) contained 13 million. ${ }^{2}$ At a much smaller scale than at the turn of the 20 th century, Argentina continues to receive immigrants. In the 1990s, a substantial number of immigrants arrived from Korea (North and South), China, and Vietnam (Mera 1998), establishing educational and religious institutions as well as a vibrant Chinatown. Today, the largest immigrant group comprises illegal immigrants, consisting of approximately 700,000 people. Most are of indigenous origins and come from neighboring countries, and since they speak Quechua, they make up the largest group of speakers of languages other than Spanish in Argentina. ${ }^{3}$ The large majority of the population is, however, monolingual. The Spanish spoken today largely reflects the country's immigrant past. As I shall now show, many idiosyncrasies in Porteño Spanish can be traced back to contact with languages spoken by immigrants. Other features of the language, however, follow patterns also observed in other Latin American varieties.

2 Numbers available on the web pages of the national Institute of Statistics and Censuses (indec.gov.ar).

3 Ethnologue (www.ethnologue.com) reports that 24 languages other than Spanish are spoken in Argentina. After Quechuan, Mapundungun, spoken in southwestern Argentina (and neighboring Chile), is the language with most speakers (100,000). 
Porteño Spanish is a relatively thoroughly studied variety of Spanish (see, especially, Colantoni \& Rodríguez Louro 2013). Since the early description of the variety by Abeille (1900 [2005]), numerous works have been published, and their emphasis may be described as follows:

a. Those describing the Porteño Spanish lexicon, from the more obscure studies (Terrera 1968) to the important Diccionario del Habla de los Argentinos (Academia Argentina de Letras 2008).

b. Those discussing the nature and impact of the varieties that appeared as a result of the massive immigration (Annecchiarico 2012). Lunfardo (to be discussed in detail below) is by far the most studied from a linguistic point of view (Carisomo et al. 2005; Conde 2011; Gobello \& Olivieri 2005), but its impact on literature has also been extensively studied, as in Borges and Clemente (1968) and Furlan (1995; 2006), to mention just two (see also Di Tullio \& Kailuweit 2011 for an overview). Cocoliche (also to be discussed below) has also received substantial attention, albeit less than Lunfardo has, presumably because the latter is still in use (Cara-Walker 1987; Kailuweit 2007; Meo Zilio 1964).

\subsubsection{Previous Research on the Porteño Spanish Perfect and Preterit}

As is well-known, what now functions as a Perfect in a majority of Romance languages arose in Latin, through a well-documented grammaticalization development, compatible (at least in its first stages) with the perfective path, which sketches the development from possessive to perfect and eventually past/past perfective. The perfective path is seen as a particularly good example of the existence of diachronic paths. A construction with the lexeme habere 'to have' gradually developed from possessive construction, to resultative, and eventually came to express perfect. ${ }^{4}$ In some languages, such as French, the Perfect has further developed into a past perfective and has thus followed the so-called perfective path (also mentioned in Chapter 1):

be/have+ participle $\rightarrow$ resultative $\rightarrow$ anterior $\rightarrow$ perfective/simple past FIGURE 2 Perfective path, after Bybee et al. (1994:105).

4 Note that there also existed a construction formed with the verb esse 'to be', used with intransitive verbs, which still exists in, e.g., French (Harris \& Vincent 1988: 229). 
In French, then, the Passé Composé expresses both past perfective and past with CR and has taken over for the Passé Simple in the spoken language. The latter is alive and well in the written language.

The French and Spanish Perfects stem from a grammaticalized construction that began its development in Latin. Originally, Latin had a synthetic verb form, somewhat confusingly labeled Perfect, which was used to express both past and past with CR (Comrie 1976: 53).

\section{(19) Cantavi}

Sing.1.SG.PAST. PFV

'I sang/I have sung'

This form evolved into the Romance Preterit, as in canté, which in many Romance varieties has past perfective meaning, as in 'I sang'.

Crucially, however, the Porteño Spanish Preterit expresses both past perfective and past with $\mathrm{CR}$, as was the case in Latin. In what follows, I provide an overview of previous research on the origins and distribution of the Porteño Spanish Preterit.

The distribution of the Perfect and Preterit in Porteño Spanish has to some extent received scholarly attention (see, e.g., Squartini 1998: 182 for a short overview; see also Fontanella de Weinberg 1987). While the general tendency is agreed upon - the frequency of the Perfect to express past with CR is low relative to frequencies in other Spanish varieties - the details of this distribution remain unclear. First, there appears to be a lack of consensus as to the origins of this low frequency; it has been proposed that in certain Latin American varieties, the original dual function of the Latin cantavi form (as discussed above) is retained, so the use of the Preterit to express past with CR is understood as an archaic feature (Penny 2000: 158-161).

The second question regards the time span of the change. Most approaches see the decrease in the use of the Perfect as a recent development. Kubarth (1992) notes a significantly lower frequency of Perfect use in young speakers (13-30 years) than in middle-aged users $(30-49)$ and argues that the Perfect may be on its way to extinction (ibid.: 565). Burgos (2004) similarly notes that the Perfect is falling into disuse but argues that other constructions and temporal adverbials make up for the lack of a grammaticalized perfect. It should be noted that the studies that point to a decrease in Perfect usage are compatible with Abeille (1900 [2005]), who surprisingly notes the frequency of the Perfect and its expansion in Porteño Spanish around 19oo. This early use of the Perfect adds to the evidence that the Perfect did indeed exist in Porteño Spanish around 1900. This development will be discussed as a possible "dead end" in 7.6.2.1. 
Third, and importantly, still debated are the semantic restrictions that condition the sparse Perfect use in Buenos Aires Spanish. One line of argumentation holds that Buenos Aires Spanish follows a "Latin American norm," in which the Perfect is restricted to durative and iterative situations that encompass speech time (i.e., persistent situation). This is the view held by Squartini and Bertinetto (2000: 413), who maintain that this pattern holds for Buenos Aires Spanish, as well as, for instance, Mexican Spanish. It will be made clear in Chapters 6 and 7 that this is not the case for present-day Porteño Spanish (see also McKenzie 1995 for critique of the "Latin American norm"; Rodríguez Louro 2009 for discussion).

Schwenter (1994), similarly to Squartini and Bertinetto, sees the use of the Perfect as following aspectual restrictions in Porteño Spanish; those situations that are not bounded (i.e., durative and iterative situations) require Perfect use. Howe and Rodríguez Louro (2013) also provide an analysis with focus on the expression of persistent situation in Porteño Spanish and other Spanish varieties. Schwenter and Cacoullos (2008) find that in Mexican Spanish, not only duaritivty, but also absence of temporal anchor triggers Perfect use. Again, in the present study; this will be shown not to be the case for Porteño Spanish speakers.

Kubarth (1992) argues that the sparse use of Perfect in young speakers is random, as opposed to Rodríguez Louro (2009) who, in line with a sociolinguistic variationist approach, argues that the variation follows structured patterns, for example, in the Perfect's being conditioned by unbound situations.

A more general observation is that (1) none of these approaches have a clear explanatory approach - that is, they make no attempt to account for the "why" of the change; and (2) they typically operate within the realm of a combination of grammaticalization theory and variationist approaches (see especially Rodríguez Louro 2009; Howe \& Rodríguez Louro 2013). In my opinion, the variation observed in the language of certain speakers of present-day Porteño Spanish has more in common with what Kubarth (1992: 565$)$ claims is "random" - at least superficially. By this I mean that we observe remnants of what is an expansion beginning in the experiential function. Both grammaticalization and variationist approaches fail to provide a clear picture of the origins of the change in question, a gap that will be the topic of this work.

Despite this difference in approach, this study makes reference to previous studies, especially that of Schwenter and Torres Cacoullos (2008). In their study, several factor groups are included to account for the distribution of the Perfect and Preterit, among which temporal reference (rather than temporal distance) will be given special importance in this study. As we shall see in 7.5.1, 
the similarities between the arguments made in the two studies are remarkable, and this study further explores the relationship between temporal indetereminacy and experiential.

\subsubsection{Linguistic Features: General}

In what follows, I summarize linguistic features characteristic of the Porteño Spanish variety of Spanish. Emphasis is on tense and aspect, but I also schematically go through other defining features of the variety in question.

\subsubsection{Tense and Aspect}

In this section, I provide an overview of the relevant tense and aspect categories in Porteño Spanish. A detailed discussion of tense and aspect was provided in Chapter 2.

Spanish has inherited a rich verbal morphology from Latin. A first division can be made between nonfinite forms and finite forms. Nonfinite forms are infinitive, gerund, and perfect participle. The finite forms refer to five verbal categories—namely, tense, aspect, mood, person, and number:

- Tense: present, past, and future

- Aspect: perfective and imperfective (tense distinctions made only in the imperfective), as well as perfect

- Mood: indicative, subjunctive, conditional, and imperative

- Person: first, second, and third

- Number, singular and plural, for each person

As discussed in section 2.3, aspect typically focuses on the internal contours of the situation, while the perfective aspect focuses on the initial and final boundaries of an event. Many languages express both tense and aspect through the same verb form; they are aspect sensitive (see 2.2.2). Spanish is one of those languages; Spanish grammatical tense and aspect are thus fused in the same morpheme and, in this way, configure the verb-inflectional system of Spanish (see Hodgson 2003 for details on acquisition of the perfective aspect in Spanish). For example, in example (20) below, the morpheme -ó in Llovió carries both the temporal value of occurring prior to the moment of speech and the aspectual value of presenting the act as complete through the perfective's ability to mark the situation's initial and final end point. When no distinct markers for tense or aspect may be morphologically segmented, we are dealing with joint marking (Lindstedt 2001: 779). 


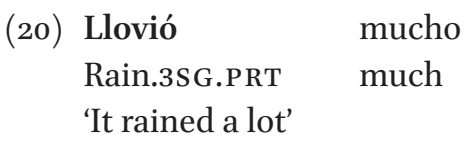

(Bybee 1985: 142)

To sum up, it is important to note that standard Peninsular Spanish has a system in which perfectivity/imperfectivity is distinguished only in the past (there is no present perfective). This is a very common type typologically, as identified by Dahl (1985), and is different from, for example, the Slavic tense and aspect systems, which have a perfective/imperfective that cross-classifies with the past and present tense completely.

As observed above, Spanish distinguishes between perfective and imperfective aspect in the past (past perfective vs. past imperfective). In addition, there is a progressive aspect that may be combined with past and present morphology.

Spanish forms Perfects through an auxiliary, which may be present or past, to form present perfects and past perfects, respectively. Notably, in section 6.4.5, I will show that the Past Perfect still is in use in Porteño Spanish, despite the demise of the Present Perfect. Traditionally, the Spanish Perfect expresses the four typical subfunctions associated with it: experiential, resultative, recent past, and persistent situation (see Chapter 2). In older sources of Porteño Spanish, this canonical use has been documented (Fløgstad 2007; see also Burgos 2004 and Rodríguez Louro 2009 for frequencies in older texts). In addition, it is important to note that persistent situation is also expressed by means of Present constructions in all varieties of Spanish, including Porteño Spanish. As discussed in 2.2.7.2, this is not uncommon. In fact, expressing persistent situation by means of Perfects, as in, for instance, English and Norwegian (in sentences such as I have lived in Oslo for 15 years and its Norwegian counterpart, Jeg har bodd i Oslo i 15 år), appears to be more rare (Comrie 1976: 60). In Spanish, then, persistent situation can be expressed by means of constructions such as the following:

(21) Perfect

HABCULT: 195

Nacido en Buenos Aires donde siempre ha residido

Born in Buenos Aires where always live.3sG.PRs.PrF

'Born in Buenos Aires, where he has always lived' 
(22) Present construction

(07:15/4)

\begin{tabular}{|c|c|c|c|c|c|}
\hline Desde & octubre & hasta & el & día & de \\
\hline ince & October & until & the & day & of \\
\hline & tiene & & trabajo & no & encontró \\
\hline NEG & have.3SG.PRS & & job & NEG & find.3SG.PRT \\
\hline
\end{tabular}

'She hasn't had a job since October; she hasn't found (one)'

Present constructions also exist to express recent past; such are typically formed with acabo de + infinitive. Note that the use of haber as possessive verb disappeared in Spanish, probably before the beginning of the 17th century (Olbertz 1991). This is different from, for instance, French, in which avoir still has a possessive meaning, and exemplifies the way in which grammaticalization affects the lexeme in a certain construction; see Chapter 2.

Given the grammaticalization of haber, it should be noted here that there exists a lexical expression of possession that has not been grammaticalized (but notably has been in Brazilian Portuguese; see 7.3.1.2): tener 'to have', as in the following:

(23) HABCULT: 208

La tesis mía tenía una parte muy buena the thesis mine have.3sG.pst.IPFV one part very good que era el prólogo that was the prologue

'My thesis had one good part that was the prologue'

\subsubsection{Morphosyntax}

Porteño Spanish uniformly uses vos 'you' as the second-person singular pronoun instead of $t u$, a phenomenon referred to as voseo. ${ }^{5}$ Vos is used by speakers of all social levels and in all contexts (but note that usted is the polite form of the second-person singular) (see Moyna 2009 for a discussion on the evolution and acquisition of the voseo). The use of vos instead of tú also entails a different conjugation of present verbs in second-person singular, as seen in (24), in which stress is on the last syllable in contás:

5 Note that the use of the voseo has been attested as early as in the 19th century and has been taken as evidence for a growing standardization and acceptance of the Porteño Spanish norm (Rodríguez Louro 2009: 2). 
(24) HABCULT: 198

Por qué no me contás lo de tu pensionado

For what NEG me tell.2sG.PRs that of your pension

de Villa devoto

from Villa Devoto

'Why don't you tell me about your pension from Villa Devoto?'

The Peninsular Spanish counterpart of (24) would be cuentas, with stress on the initial syllable. Furthermore, as in all of Latin America, ustedes 'you' is the second-person plural and has the same conjugation as the third-person plural masculine/feminine, ellos/ellas 'them'.

In addition, like most other Latin American varieties, Porteño Spanish has clitic doubling of definite personal direct-object nouns, as in (25), whereas lo would be incorrect and ungrammatical in other varieties (Gabriel \& Rinke 2010).

$\begin{array}{lll}\text { (25) Lo conozco } & \text { a Juán } \\ \text { Him know.1SG.PRS to Juán } \\ \text { 'I know Juán' }\end{array}$

Subjunctive verbs in subordinate clauses appear in the present tense, even though the verb in the main clause may require past tense reference, as in (26):

$\begin{array}{llllll}\text { Me pidió } & \text { que } & \text { le } & \text { haga } & \text { un } & \text { favor } \\ \text { Me ask.3SG.PRT that him } & \text { make.1SG.PRS.SBJV } & \text { a } & \text { favor } \\ \text { 'He asked me to do him a favor' } & & & \end{array}$

(Lipski 2012: 14-15)

\subsubsection{Phonology}

Two phonological features are typical of Porteño Spanish. Yeísmo refers to the loss of the traditional palatal lateral approximant phoneme $/ K /$ (written $\langle l 1\rangle$ ) and its merger into the phoneme / $/$ / (written $\langle y\rangle)$. In Porteño Spanish, however, this phoneme is realized as [ $\left.\int\right]$. The original sound was voiced, but the devoicing is spreading throughout Argentina, and younger residents of Buenos Aires now pronounce it $\left[\int\right]$.

A further phonological characteristic is the reduction of preconsonantal /s/, which is typically reduced to [h] (aspirated) in the contexts _C and _\#\#C. In this respect, Argentinean Spanish is assumed to be at a less advanced stage than, for instance, Cuban Spanish, in which /s/ is also reducing at the end of words (Bybee 2001: 140-141). 


\subsubsection{Prosody}

Porteño Spanish differs from Peninsular Spanish in that the peak of the rising pitch movement in broad-focus declaratives occurs earlier in Porteño Spanish: it reaches its peak at the beginning or at the center of the stressed syllable and not directly after the stressed syllable, as in Peninsular Spanish (Benet et al. 2012; Colantoni \& Gurlekian 2004). This property of Porteño Spanish is assumed to be due to the "Italianization" of Porteño Spanish as a consequence of the massive Italian immigration to the area, as discussed in sections 3.2 and 7.8. Note that this feature is unique to the Buenos Aires variety and is not found in, for example, Uruguayan Spanish, which also experienced influences from Italian immigration (see 7.8 for discussion of the linguistic consequences of immigration).

\subsubsection{Lexicon}

The Porteño Spanish lexicon is heavily influenced by the considerable immigration to the area, and it is particularly Italian that has made its mark on the variety (Conde 2004; Gobello \& Olivieri 2005). The Italian loanwords generally restrict themselves to the intimate sphere: food, family, ordinary life, and so on (Conde 2011: $82-83$ ). Of the Italian varieties, it is the Genovese variety that is assumed to have had the most influence on the Porteño Spanish lexicon (Conde 2011; Gobello \& Olivieri 2005) (but note that the Southern Italian varieties are seen to have had most impact on the prosodic system; see discussion in 7.8.1). As observed above, the most-studied outcomes of the lexical impact Italian exercised on Porteño Spanish are the varieties known as Lunfardo and Cocoliche.

Lunfardo is defined as a vocabulary used by many Porteño Spanish speakers in addition to, or perhaps in contrast to, the standard Porteño Spanish variety (Gobello \& Olivieri 2005), resembling a stylistic variety more than a distinct language. Its origins are disputed; some claim it was created as a criminal argot in which words were deliberately substituted with non-Spanish counterparts to misinform the non-natives. The Lunfardo lexicon is most typically Italian, and Italian immigrants were indeed instrumental in creating it at the turn of the 2oth century. It also, however, includes loans from other varieties, such as English, French, and so on. As for today, it is unclear whether this use of Lunfardo is actually found in spontaneous speech (in this way resembling, e.g., Para-Romani varieties; see Matras \& Bakker 2003: 7). It is not, as often claimed, the language of outlaws; rather it has Northern Italian dialects as its lexical base (ibid.: 11). Above all, Lunfardo reflects the lexical impact Italian dialects had on the Porteño Spanish language. Lunfardo is still in use, today more as a preferential use of a particular lexicon, often associated with 
intonational and segmentational pronunciation that typifies tendencies of the lower classes.

The literature on Lunfardo is particularly rich; see Annecchiarico (2012), Carisomo et al. (2005), Conde (2011), Di Tullio and Kailuweit (2011), and Gobello and Olivieri (2005), to mention a few recent publications. The literature seems inconclusive, however, when it comes to drawing a line between actual Lunfardo and the Italian impact reflected in the now-standard Porteño Spanish variety (Conde 2011). It is also sometimes claimed that literature was crucial in the spread of Lunfardo (as argued by, e.g., Gobello \& Olivieri 2005; but cf. Conde 2011: 126).

Cocoliche was a hybrid of Northern Italian and Spanish spoken in the port areas of Buenos Aires more than 100 years ago. While Lunfardo was used by immigrants and the native population alike (and is still today), Cocoliche was used by Italian immigrants only and was their rule-governed interlanguage on their way to acquiring Spanish (for more on the notion of interlanguage, see Sankoff 2001: 639). As they acquired Spanish, their use of Cocoliche disappeared. Its name, "Cocoliche," stems from the name of a fictional character, Antonio Cocoliche, in a dramatized performance of a novel by author Eduardo Gutierrez. Antonio Cocoliche's way of speaking-a broken, lower-class Italian-became popular among Argentineans, to the extent that the term "Cocoliche" now refers not only to the actual way in which immigrants spoke but also to a literary "genre," mock Cocoliche, a stereotyped and exaggerated version of the actual variety (Cara-Walker 1987).

Whinnom (1971) defines Cocoliche as a modified version of Italian that immigrants spoke, ranging from nonstandard Italian to nonnative Porteño Spanish, including different adjustments to the Spanish spoken in the area. Among these adjustments were import into the Italian morphosyntactic and phonological system without adjustment of the latter (ibid.: 98).

Although its resemblance to a pidgin has been discussed, the majority of scholars have concluded that several factors make Cocoliche not so. Whinnom (1971) and Bickerton (1976: 171) seem to agree that Cocoliche does not constitute a pidgin as it was too transitory and unstable to be identified as a distinct language. ${ }^{6}$ More importantly, Cocoliche shows no signs of grammatical or lexical simplification otherwise associated with pidgins (Conde 2011: 174). A more pertinent definition is therefore that Cocoliche resembled the interlanguage of Italian immigrants adjusting to Spanish, as mentioned above. Similarly, Gobello and Olivieri (2005) argue that Cocoliche was Italian immigrants' first attempt to adjust to the majority language (hence interlanguage),

6 Note the absence of Spanish Creoles; see, for example, McWhorter (2000). 
while Lunfardo was the second variety that emerged and is also a variety that survived. Note also that other immigrant varieties emerged at the peak of the immigration; Valesco was the interlanguage - or language of transition - of the thousands of immigrants who came from the Valaquian province in southern Romania.

\subsubsection{Uruguayan Spanish}

The interviews with Uruguayan informants were conducted in Dolores, a small town of 14,000 inhabitants in the department of Soriano; and in Montevideo, the country's capital, with 1.5 million inhabitants, approximately half of Uruguay's population. ${ }^{7}$ These cities both belong to what is referred to as the Río de la Plata zone. Here, I provide a short overview of the socio-historical context and previously conducted research.

\subsubsection{Uruguay: Historical and Demographic Profile}

Uruguay-sometimes referred to as "the Switzerland of South America"-is situated between Argentina, Brazil, and Paraguay and has a population of only 3.3 million. ${ }^{8}$ After recovering from intense civil wars and political instability in the early 19th century, it soon became a country of wealth and democratic values. In 1917, it was one of the first countries to allow divorce and, similarly, one of the first to allow female suffrage. As early as 1877 , Uruguay established a free, obligatory, and secular educational system. In addition, $68 \%$ of the Uruguayan population has been estimated to belong to the middle class, which is an unusually high number compared to other Latin American countries having larger class differences and smaller middle classes.

Perhaps precisely because of this wealth and relative political stability, Uruguay became a destination for European immigrants before Argentina did, which created a flow of immigrants from Italy, France, and Spain. In 186o, Montevideo's population consisted of $48 \%$ foreigners (compared to only $36 \%$ in Buenos Aires). At that time, $28 \%$ of immigrants were Spanish, $27 \%$ Italian, and $22 \%$ French, mainly Basques. Immigrants tended to cluster in the capital. These numbers are strikingly similar to those of Buenos Aires in 1887 (see 3.2). It has been claimed, therefore, that the differences between immigration to Uruguay and Argentina were mostly quantitative rather than qualitative and that the importance of immigration has been similar in the development of Uruguay as in that of Buenos Aires (Di Tullio \& Kailuweit 2011:15).

7 Interviews were conducted in Buenos Aires, Dolores and Montevideo, and they are discussed in detail in Chapter 5 .

8 Numbers available at the Uruguayan Insituto Nacional de Estadistica; ine.gub.uy. 
Similarities aside, there were also differences between the two countries in the way in which immigrants settled and lived. Uruguay soon failed to maintain its position as a top choice of European immigrants. It soon became a country of transit rather than of permanent settlement. Between 1874 and 1901, only 1,596 foreigners became Uruguayan citizens. Immigration to Uruguay was small in relative numbers compared to that of neighboring Argentina. In the decade between 1905 and 1914, the ratio of new immigrants to the total population of Uruguay was only one-tenth of that for Argentina (Finch 1981). As will be discussed in Chapter 7 , this fact may be important in understanding the rapid spread of the Preterit in Buenos Aires Spanish as opposed to in Uruguayan Spanish.

\subsubsection{Previous Research}

Uruguayan Spanish has largely been ignored by scholars of linguistics and Latin American Spanish. To the extent that it has been addressed, what little has been written is generally defined by two important generalizations: first, treating "Uruguayan Spanish" as a homogeneous entity, and second, assuming that its similarities with Buenos Aires Spanish are such that they may well be treated as one. Lope Blanch (1968) states that works on Porteño Spanish are also applicable to Uruguayan Spanish. The same is argued by Lipski (1994), who maintains that Montevideo Spanish is indistinguishable from Buenos Aires Spanish. Tullio and Kailuweit (2011) similarly include Uruguayan Spanish in an otherwise thorough edition on the Porteño Spanish variety. Thus, from the viewpoint of a majority of scholars, Uruguayan Spanish has been treated as indistinguishable from Buenos Aires Spanish (but cf. Bertolotti 2011 and Elizaincín 1981 for notable attempts in the opposite direction).

The one Uruguayan variety that has been most extensively treated is Portuñol (also referred to as Portunhol and Fronterizo) (Carvalho 2004; Klee \& Lynch 2009; Lipski 2006; Rona 1960). Portuñol, spoken around the border between Uruguay and Brazil, incorporates both Portuguese and Spanish elements. Carvalho (2004) reports that Fronterizo differs from standard Brazilian but mainly in phonology, in the lexicon, and in the retention of rural features (which ones are not specified) otherwise not present in urban Brazilian Portuguese. Lipski (2006), in an informative discussion on the genesis of Portuñol, does not discuss tense/aspect; neither do Klee and Lynch (2009). Lipski (ibid.) does provide an extensive collection of Fronterizo texts, in which the Perfect is absent. He also notes the existence of Spanish verb endings attached to Portuguese verb stems, as in the following Preterit example, in which the verb 'play' is formed through a combination of the Spanish past perfective suffix -é attached to the Portuguese stem of jogar: 


\section{(27) Joguê}

Play.1SG.PRT

'I played/I have played'

This indicates that the Preterit indeed exists in this variety, but more sources are needed to establish its distribution and meaning.

\subsubsection{Previous Research on Preterit/Past Perfective in Uruguay}

The Preterit/Perfect distinction in Uruguayan Spanish has received minimal attention. Lipski (1994) maintains that Montevideo Spanish is indistinguishable from Buenos Aires Spanish and argues that there is nothing in the syntax or morphology that makes Uruguayan Spanish different from other Latin American varieties. Whether this should be taken to mean that Montevideo Spanish shares all traits with Buenos Aires Spanish, even the restricted use of the Perfect, is unclear. Recent sources are rare, but Henderson (2010) notes that the Perfect is used rather frequently to express past with CR in Montevideo Spanish and that this usage differs from that of Buenos Aires speakers in its mere frequency in current relevance contexts.

The study of Uruguayan Spanish is thus a field that requires more research in all aspects of the language. It is likely that this lack of research on Uruguayan Spanish stems from its proximity to Argentine Spanish, both geographically and linguistically.

It is important to note that even though Montevideo Spanish is considered Rioplatense Spanish, and does share important features with the language spoken across the river, there are important differences. The falling pitch typical to Buenos Aires Spanish is absent from Montevideo Spanish. The use of the personal pronoun $t u ́$ is widespread in various varieties of Uruguayan Spanish but rare in Buenos Aires Spanish (Elizaincín 1981). When it comes to the use of the Perfect and Preterit, the distribution is different from that in Buenos Aires Spanish. As we shall see, and as has also been confirmed by Henderson (2010), the Uruguayan speakers in this study employ the Perfect far more frequently than do Buenos Aires speakers. This study is therefore a much-needed contribution to the study of a largely neglected linguistic area. 